\title{
Low-Cost Technologies for Mining Wastewater
}

\section{Treatment}

\author{
Mike Agbesi Acheampong ${ }^{1}$ and Ebenezer David Okwaning Ansa ${ }^{2}$ \\ 1. Department of Chemical Engineering, Kumasi Technical University, Kumasi, Ghana \\ 2. Water Research Institute, Council for Scientific \& Industrial Research, Accra, Ghana
}

\begin{abstract}
The mining industry has contributed tremendously to the global economy. However, waste generated by this activity poses many challenges. Current low-cost technologies for the removal of heavy metals from mining wastewater include biosorption, adsorption, CWs (Constructed Wetlands) and waste stabilization ponds. This chapter focuses on sustainable mining wastewater treatment technologies with emphasis on gold mining wastewater. It discusses the technical and environmental challenges associated with mining effluent treatment, process conditions for optimum plant performance, efficiency, limitations and the economics of treating mining wastewater. The overall treatment cost of metal contaminated wastewater depends on the process employed and the local conditions. In general, technical applicability, cost-effectiveness and plant simplicity are the key factors in selecting the most suitable treatment method. Proper management of the spent biosorbent and solid wastes generated is also discussed.
\end{abstract}

Key words: Removal, heavy metal, biosorption, waste stabilization pond, CW (Constructed Wetland), mining wastewater.

\section{Introduction}

Heavy metals occur in immobilized form in sediments and as ores in nature. Various human activities like ore mining and industrial processes disrupt the natural biogeochemical cycles causing increased deposition of heavy metals in terrestrial and aquatic environments. Heavy metals are found in wastewater discharged from industries such as mining, metal processing, electroplating, textile, tannery and petroleum refinery [1-5]. Heavy metals such as As, Cu, Pd, Zn, Fe, Cr, Ni and $\mathrm{Hg}$ are toxic [6-8] and therefore the discharge of untreated metal-laden effluent from the mining industry poses serious environmental challenges [9, 10]. Sorption using natural and agricultural materials has been proposed as a cost effective and environmentally friendly alternative to chemical treatment [11-14].

The discovery and further development of biosorption phenomena provide a basis for a whole

Corresponding author: Mike Agbesi Acheampong, associate professor, research fields: chemical engineering, environmental engineering/biotechnology, sorption and biosorption, water quality, water, wastewater treatment and solid waste management. new technology aimed at the removal of various pollutants or the recovery of valuable resources from aqueous systems. Although there are many industrial processes using sorbents such as activated carbon, the development of biosorption processes is still mainly at the stage of laboratory studies in spite of enormous progress made over the last decade [15]. Most studies on continuous biosorption systems have focused mainly on the optimisation of operating conditions and breakthrough curves using synthetic metal solutions [16-21]. Many of these studies have limited industrial application because industrial effluents are more complex, containing several metal ions and other contaminants [22]. Singh, A., et al. [22] indicated that treatment of industrial effluent in continuous flow through systems allows the use of biosorbents for multiple biosorption and desorption applications. In this way, process sustainability is achieved through a substantial reduction in the fresh sorbent requirement, operational cost and solid waste materials needing disposal or containment $[4,15]$.

WSPs (Waste Stabilization Ponds) are common technologies for industrial wastewater treatment due 
to their low capital and operating costs. They are particularly popular in locations where large tracts of land are available and affordable. In spite of the popularity of WSPs, limited studies on the use of this technology for the removal of heavy metals from mining wastewater had been conducted [23]. The few studies conducted on WSPs have shown a poor performance in the removal of metals [23-25]. Due to this limitation of scanty literature availability, greater attention is paid to the use of CWs (Constructed Wetlands) for mining wastewater treatment.

CWs are artificial or engineered wetlands developed to utilize the natural, physical, biological and chemical processes that take place in these aquatic ecosystems involving the soil, flora and fauna, including its microbial communities, to treat wastewater [26]. The use of CWs for the removal of heavy metals is a very recent development. CWs are used for the treatment of wastewater from mining, oil refineries, chemical factories, pulp and paper production, tannery, textile, abattoir, distillery, winery and other industries as well as various runoff waters from airports and highways as various sources of industrial wastewater, noting limited studies done on wastewater from mines [26]. This is because the treatment of wastewater from mines had not been given much attention in literature [27], as results that monitoring programmes by mining companies are usually not published in peer reviewed journals.

\section{Technological Options for the Removal of Heavy Metal from Mining Wastewater}

Currently, sustainable technologies for the removal of heavy metals from mining wastewater include biosorption, adsorption, CWs and waste stabilization ponds, among others.

\subsection{Biosorption}

Wang, J. and Chen, C. [28] defined biosorption as the removal of metal and metalloid species, compounds and particulates from solution by biological material. Biosorption is made possible by the ability of biological materials to accumulate heavy metals from wastewater through metabolically mediated or physico-chemical uptake pathways.

2.1.1 Understanding Metals Biosorption Mechanism during Mining Wastewater Treatment

Due to the interaction of several factors on specific biosorbents, it is almost impossible to propose a general mechanism. Although several metal-binding mechanisms have been put forward, e.g. physical and chemical adsorption, ion exchange and microprecipitation, the actual mechanism of metal biosorption is still not fully understood [29].

Ion-exchange is an important concept in biosorption, because it explains many observations made during heavy metal uptake experiments [30]. Ion-exchange is a reversible chemical reaction where an ion within a solution is replaced by a similarly charged ion attached onto an immobile solid particle [31]. This ion-exchange process is one of the well-known surface reactions, which represents a great degree of complexity, primarily due to its multi-species nature. In bacterial biosorption, the bacterial cell wall is the first component that comes into contact with the metal, where the solute can be deposited on the surface or within the cell wall structure [32]. Since the mode of solute uptake by dead or inactive cells is extracellular, the chemical functional groups of the cell wall play vital a role in biosorption.

Another frequently encountered metal binding mechanism is chelation, which can be defined as a firm binding of metal ions with an organic molecule (ligand) to form a ring structure [29]. Various functional groups including carboxylic, hydroxyl, sulphate, phosphate, amides and amino groups can be considered possible for sorption. Among these groups, the amino group is the most effective for removing heavy metals, since it does not merely chelate cationic metal ions but also absorbs anionic species through the electrostatic interaction or hydrogen bonding. As 




Fig. 1 Major binding groups for biosorption [33].

they are negatively charged and abundantly available, carboxyl groups actively participate in the binding of metal cations [34]. Fig. 1 shows major functional groups involve in metal binding.

Agricultural and plant waste materials, such as coconut husk and shell, are usually composed of lignin and cellulose as the main constituents. Other components present in the metal binding process are hemicellulose, lipids, proteins, simple sugars, starches, water, hydrocarbons and many more compounds that contain a variety of functional groups [35]. The presence of these functional groups and their complexation with heavy metals during biosorption has been reported by different researchers using spectroscopic techniques.

Benavente, M., et al. [10] reported the treatment of gold mining wastewater using chitosan and found that the removal of $\mathrm{Cu}, \mathrm{Pb}$ and $\mathrm{Zn}$ was not affected by the presence of other metals because they were present at low concentrations. The speciation of metallic ions in gold mining tailings wastewater depends on their oxidation states, the metallic ion concentrations, the cyanide concentration, the redox potential, the temperature and $\mathrm{pH}$ of the wastewater [10]. Benavente, M., et al. [10] indicated that the presence of cyanide had a negative impact on the sorption process, but not to the extent of affecting the removal of copper significantly, as evident from the low copper concentration $\left(<0.01 \mathrm{mg} \cdot \mathrm{L}^{-1}\right)$ in their treated effluent. Similar to the findings of Benavente, M., et al. [10],
Acheampong, M. A. and Lens, P. N. [36] observed that neither the presence of cyanide nor other heavy metals inhibited the removal of copper from gold mining effluent studied.

According to Saad, D. M., et al. [37], metal-cyanide complexes and free metallic ions were mainly present in the gold mining wastewater at $\mathrm{pH}$ 7.7. They indicated that the speciation results for the tailings dam show that copper, lead and zinc were mostly found as free metallic ions with only a small fraction present as metal-cyanide complexes. This is, however, contradictory to well-established experimental science of metallocyanide species in tailings waters. The most commonly encountered iron cyanide complexes are the two formed with ferrous and ferric iron, $\mathrm{Fe}(\mathrm{CN})_{6}{ }^{4-}$ and $\mathrm{Fe}(\mathrm{CN})_{6}^{3-}$, respectively [38]. The $\mathrm{Fe}(\mathrm{III})$ complex being the predominant species is found in mining tailings solutions. The formation of hexacyanoferrate(III) is primarily the result of the oxidation of hexacyanoferrate(II) in surface impoundments. However, typically within solid tailings environment, the oxidation potential would result in the formation of ferrocyanide precipitates [39]. The hexacyanoferrates are classified as "inert" complexes, in that their chemical stability results from extremely slow rates of dissociation and relatively low toxicity [38]. The overall effect is the reduction in the free metallic ions present and an increase in the proportion of the metal-cyanide complexes in the tailings solutions.

When present in cyanide tailings solutions, copper is predominantly present as a mix of three forms: $\mathrm{Cu}(\mathrm{CN})_{2}{ }^{-}, \mathrm{Cu}(\mathrm{CN})_{3}{ }^{2-}$ and $\mathrm{Cu}(\mathrm{CN})_{4}{ }^{3-}$ [39]. The $\mathrm{Cu}(\mathrm{II})$ cyanide species are unstable in aqueous solution and disproportionate to the $\mathrm{Cu}(\mathrm{I})$ cyanides. While the formation of metal cyanide complexes does not completely eliminate the toxicity of cyanide, it does effect a substantial reduction in such toxicity. Metal cyanide complexes are also intermediates involved in the formation of more stable compounds that remove free cyanide from the tailings environment. Kunz, R. G., et al. [40] described a process where copper was 
complexed with cyanide to enhance the adsorption and oxidation of cyanide onto activated carbon. The environmental significance of complexation of cyanide with heavy metals is that it is relatively rapid and it occurs wherever soluble species of these metals are present, such as found in gold mining tailings. It reduces the toxicity of free cyanide and acts as an intermediary to reduce cyanide mobility via adsorption onto organic and inorganic surfaces or precipitation of metal cyanide salts [39].

In treating electroplating wastewater using sugar cane bagasse, Sousa, F. W., et al. [12] reported a considerable decrease in adsorption of zinc and nickel, probably due to electrostatic repulsive forces between the cationic sugar cane bagasse surface and the metal ions. In contrast, Acheampong, M. A. and Lens, P. N. [36] reported that coconut shell used in their study was negatively charged at the gold mining effluent $\mathrm{pH}$ due to the lower point of zero charge $\mathrm{pH}$ of 6.5. Ahmed, M. J. K. and Ahmaruzzaman, M. [41] suggested that the removal of the positively charged heavy metals from gold mining effluent could be enhanced by electrostatic attraction forces between the biosorbent and the sorbate.

\subsubsection{Process Conditions}

The investigation of factors affecting the efficiency of heavy metal sorption is of great interest for the industrial community. The efficiency is strongly influenced by the physico-chemical characteristics of the solutions, such as $\mathrm{pH}$, temperature, initial metal concentration, presence of other ions and sorbent dosage [42]. These factors are important in evaluating the maximal sorption performance of any sorbent. The solution $\mathrm{pH}$ is a crucial factor in heavy metal sorption. The $\mathrm{pH}$ value significantly influences the dissociation of the sorbent and the solution chemistry of the heavy metals, i.e. metal speciation, hydrolysis, complexation by organic and/or inorganic ligands, redox reactions and precipitation are all $\mathrm{pH}$ dependent [29, 43, 44]. Competition between cations and protons for binding sites means that sorption of metals like $\mathrm{Cu}, \mathrm{Cd}, \mathrm{Ni}, \mathrm{Co}$ and $\mathrm{Zn}$ is often reduced at low $\mathrm{pH}$ values [42]. Due to the importance of $\mathrm{pH}$ in sorption, many researches were conducted on its effect on the removal of various heavy metals.

Depending on the structure and surface functional groups of a sorbent, temperature has an impact on the adsorption capacity within the range of $20-35^{\circ} \mathrm{C}$ [45]. It is well known that a temperature change alters the adsorption equilibrium in a specific way determined by the exothermic or endothermic nature of a process [29]. Higher temperatures usually enhance sorption due to the increased surface activities and kinetic energy of the solute. However, physical damage can be expected at higher temperatures [32]. It is always desirable to evaluate the sorption performance at room temperature, as this condition is easy to replicate.

Another important parameter in biosorption is the ionic strength, which influences the adsorption of solute to the biomass surface. Industrial wastewater often contains ions other than heavy metal ions, e.g., $\mathrm{Na}^{+}, \mathrm{K}^{+}, \mathrm{Mg}^{2+}$ and $\mathrm{Ca}^{2+}$, which may interfere with heavy metal ion uptake by biomass. As a general trend, the metal uptake is found to decrease with increasing ionic strength of the aqueous solution as a result of more electrostatic attraction and change of the metal activity [29, 43, 46, 47].

The amount of biomass in the solution also affects the specific metal uptake. For lower values of biomass concentrations, there is an increase in the specific uptake [48]. Gadd, G. M., et al. [48] suggested that an increase in biomass concentration leads to interference between the binding sites. By increasing the adsorbent dosage, the adsorption efficiency increases even though the amount adsorbed per unit mass decreases. In principle, with more adsorbent present, the available adsorption sites or functional groups also increase. In turn, the amount of adsorbed heavy metal ions increases, which results in an improved adsorption efficiency [29, 49-52].

The size of the biosorbent also plays a vital role in biosorption. Smaller sized particles have a higher 
surface area, which in turns favours biosorption and results in a shorter equilibrium time. Simultaneously, a particle for biosorption should be sufficiently resilient to withstand the application of pressure and extreme conditions applied during regeneration cycles [53]. Therefore, preliminary experiments are necessary to determine the suitable size of a biosorbent.

\subsubsection{Process Configuration}

Due to the concentration difference driving force for sorption (between the sorbate in the solution and that already sequestered), generally the most effective configuration of the sorption system is that based on a flow-through fixed bed type of a reactor/contactor (Fig. 2). The sorption column would generally not exceed approximately $1.8 \mathrm{~m}$ in diameter and 4-5 $\mathrm{m}$ in height. The scaling up of the process to accommodate larger flows is attained by simply multiplying the number of columns that would operate in parallel. Rarely, usually because of special process requirements, a mixed contactor could also be used. Different, usually multi-stage, counter-current configurations could then be arranged. The most important criterion in the design of fixed-bed sorption systems is the prediction of the column breakthrough or the shape of the adsorption wave front, which determines the operating life-span of the bed. Fig. 2 shows a typical of fixed-bed sorption systems for treating gold mining effluent.

\subsubsection{Process Performance}

The overall performance of the processes based on the sorption column mode of operation is judged by the column operating time (until the column sorption capacity is exhausted), characterized by the sorbate break-through point as determined at the column exit (Fig. 3). Since the fixed-bed column does get eventually saturated, a process arrangement is often used whereby one column is in active sorption operation while another one is being prepared (regenerated and cleaned) during its stand-by period. That column preparation usually consists of elution of the sequestered sorbate with simultaneous or sequential sorbent regeneration, clean-up and washing. Sorbent regeneration capacity is an important characteristic that results in a better overall process economy.

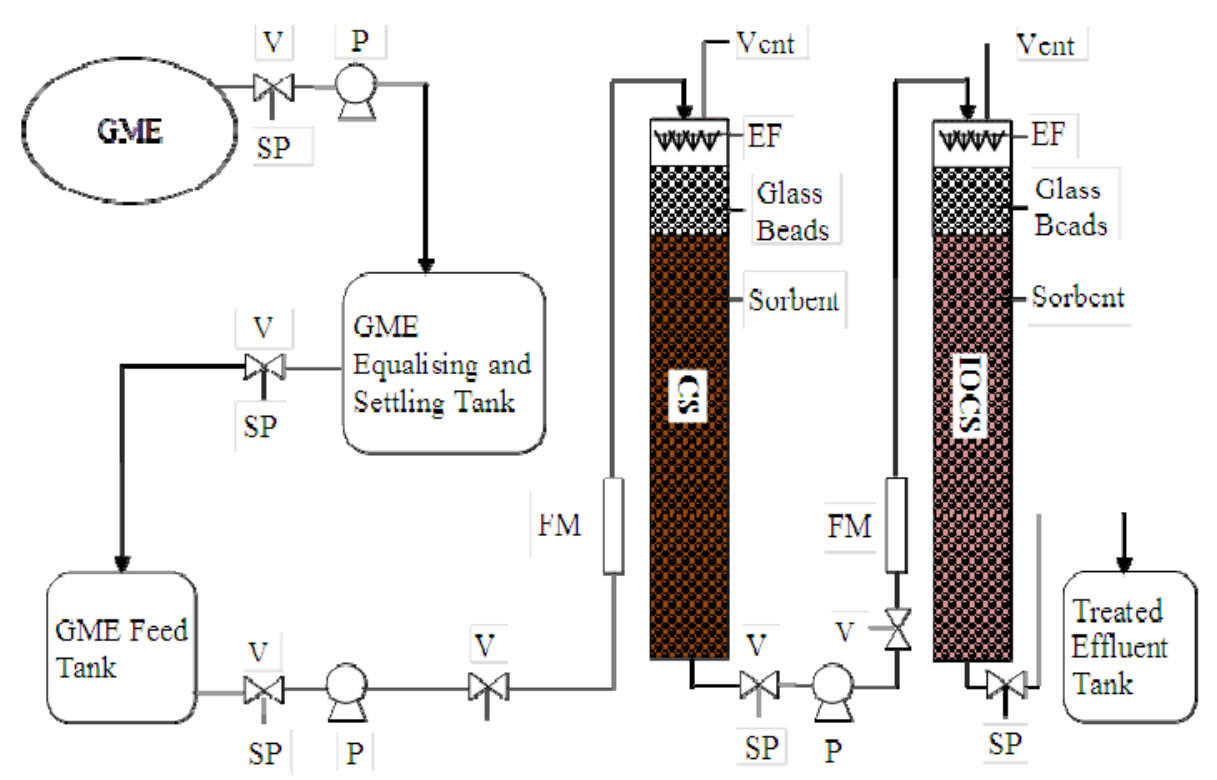

Fig. 2 Schematics diagram of a two-stage pilot plant set-up for treating gold mining effluent (CS: Coconut Shell; IOCS: Iron Oxide Coated Sand; EF: Effluent Distributor; P: Pump; SP: Sampling Point; V: Valve; GME: Gold Mining Effluent; FM: Flow Meter) [36]. 


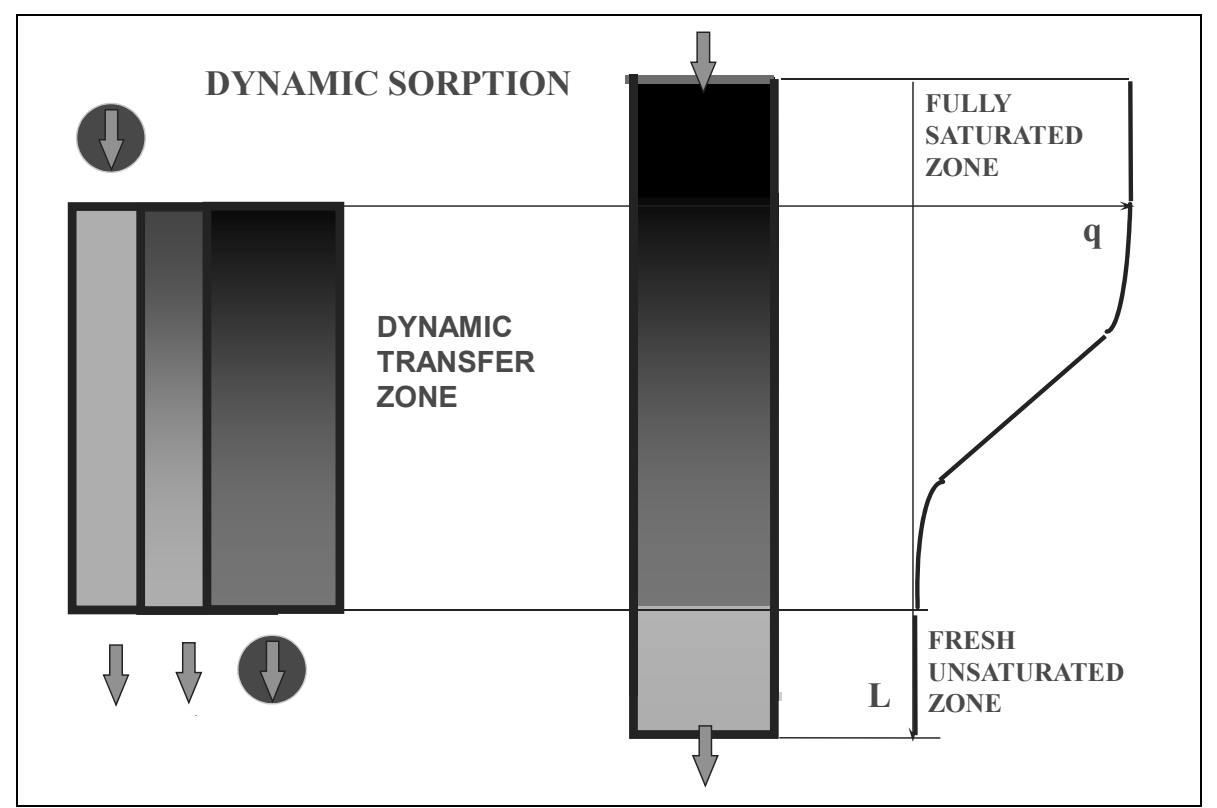

Fig. 3 Schematic representation of the development of dynamic transfer zone in the continuous-flow fixed bed sorption column [36].

\subsubsection{Sorbent Regeneration and Metal Recovery}

One of the main attributes of biosorption is the potential of sorbent regeneration and metal recovery $[52,54]$. Desorption of sorbed metals from loaded sorbent enables reuse of the sorbent and recovery and/or containment of the sorbed metals from a highly concentrated eluant stream [42, 52]. In some cases, desorption treatment may further improve the sorption capacities [55], although in other cases there may be a loss of sorption efficiency and even a complete disintegration of the biosorbent [56]. To improve process viability, better understanding of the sorption-desorption processes in sorbent regeneration is needed. The acid-based metal desorption may be followed by further steps to prepare the biosorbent for the most efficient subsequent uptake cycle. This may entail pre-saturating the active sites of the biomaterial with more $\mathrm{pH}$-neutral calcium or potassium cations in order to avoid an uncontrollable acidic wave inside the column caused by the release of ion-exchanged protons. Some overall process optimization may be useful in this respect.

Metal recovery is a down-stream consideration that has been added to the metal removal aspect, which is driven predominantly by environmental detoxification considerations. The sorption and desorption processes offered the opportunity for an economical recovery of metals from the concentrated solution. The feasibility of the recovery operation depends, to a large degree, on the type of recovery procedures used. The spent sorbents generated at the end of the process must be properly and safely disposed. Various disposal options that are in conformity with local solid waste management practice are employed.

\subsubsection{Process Integration}

For a successful industrial application biosorption technology for the sustainable treatment of mining wastewater, the integration of the sorbent processing and formulation, sorption-desorption application, metal recovery for reuse and the disposal of the spent biomass (Fig. 4) is very critical. Where the treated effluent does not meet the regulatory discharge requirement, a further polishing step using WSPs and CWs is applied.

\subsection{WSPs and CWs}

The extraction of metals such as gold, zinc, lead, copper, iron, aluminium and many others involves the release of many contaminants that may pose serious threat to public health or wildlife and therefore had to 


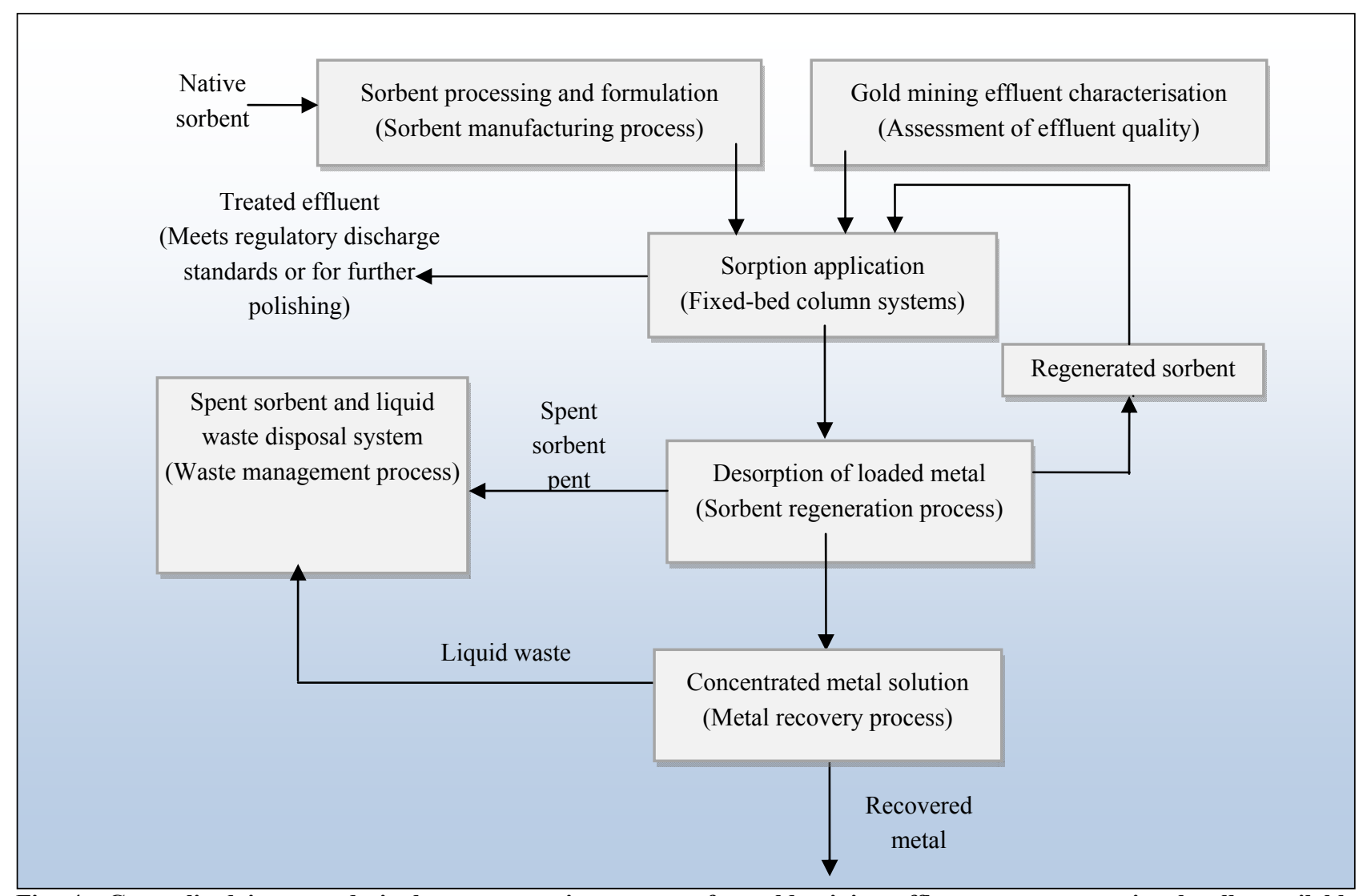

Fig. 4 Generalised integrated single stage sorption systems for gold mining effluent treatment using locally available low-cost materials.

be removed or converted to various forms that are not toxic. The contaminants include heavy metals such as zinc, copper, lead, chromium, iron and manganese, cyanide, phosphate, carbonates, sulphides, sulphates, arsenic and its complexes, nitrogen and its compounds [57]. A detail list of the concentrations of the constituents of typical mining activity wastewater is outlined in Table 1.

WSPs are common technologies for wastewater treatment due to their low capital and operating costs. They are particularly popular in locations where large tracts of land are available and affordable. Inspite of the popularity of WSPs, very limited studies on the use of this technology for the removal of heavy metals as pertains in mining wastewater had been conducted [23]. The few studies conducted on WSPs have shown a poor performance in the removal of metals [23-25]. Due to this limitation of scanty literature availability, greater attention would be paid to the use of CWs.
CWs are artificial or engineered wetlands developed to utilize the natural, physical, biological and chemical processes that take place in these aquatic ecosystems involving the soil, flora and fauna, including its microbial communities to treat wastewater. The use of CWs for the removal of heavy metals is a very recent development. In his review of the use of CWs in industrial wastewater treatment, Vymazal, J. [26] mentioned the oil refineries, chemical factories, pulp and paper production, tannery and textile industries, abattoir, distillery, winery and other food processing industries as well as various runoff waters from airports and highways as various sources of industrial wastewater, noting limited studies done on wastewater from mines. This is because the treatment of wastewater from mines had not been given much attention in literature [27], as results that monitoring programmes by mining companies are usually not published in peer reviewed 
Table 1 Typical constituents of wastewater from different mining activity [57, 62, 63].

\begin{tabular}{llll}
\hline \multirow{2}{*}{ Key parameters } & \multicolumn{3}{c}{ Sources of wastewater } \\
\cline { 2 - 4 } $\mathrm{pH}$ & Gold mining & Zinc and lead mining & Zinc-rich acid mine drainage \\
Conductivity & $701-8.6$ & 23 & 3.58 \\
$\mathrm{TSS}$ & $94-979 \mathrm{mS} / \mathrm{m}$ & $2,495 \pm 182 \mathrm{mg} / \mathrm{L}$ & \\
$\mathrm{Mg}$ & $31-1,488 \mathrm{mg} / \mathrm{L}$ & & $19.0 \mathrm{mg} / \mathrm{L}$ \\
$\mathrm{Ca}$ & & & $136 \mathrm{mg} / \mathrm{L}$ \\
$\mathrm{Li}$ & $0.22-2.8 \mathrm{mg} / \mathrm{L}$ & \\
$\mathrm{Na}$ & $14-114 \mathrm{mg} / \mathrm{L}$ & & $14.3 \mathrm{mg} / \mathrm{L}$ \\
$\mathrm{K}$ & $4.7-114 \mathrm{mg} / \mathrm{L}$ & $12.3 \mathrm{mg} / \mathrm{L}$ \\
$\mathrm{Al}$ & & $0.077 \pm 0.024 \mathrm{mg} / \mathrm{L}$ & $12.2 \mathrm{mg} / \mathrm{L}$ \\
$\mathrm{As}$ & $41-40 \mu \mathrm{g} / \mathrm{L}$ & & \\
$\mathrm{Sb}$ & $35-160 \mathrm{mg} / \mathrm{L}$ & $14.47 \pm 8.37 \mathrm{mg} / \mathrm{L}$ & $552 \mathrm{mg} / \mathrm{L}$ \\
$\mathrm{Zn}$ & & $11.49 \pm 7.7 \mathrm{mg} / \mathrm{L}$ & \\
$\mathrm{Pb}$ & & $0.0003 \pm 0.0002 \mathrm{mg} / \mathrm{L}$ & \\
$\mathrm{Hg}$ & & & \\
$\mathrm{Ni}$ & $37-69 \mu \mathrm{g} / \mathrm{L}$ & $0.05 \pm 0.04 \mathrm{mg} / \mathrm{L}$ & $17 \mathrm{mg} / \mathrm{L}$ \\
$\mathrm{Cd}$ & & & \\
$\mathrm{Fe}$ & $67-109 \mu \mathrm{L} / \mathrm{L}$ & & \\
$\mathrm{Mn}$ & $0.42-1.3 \mathrm{mg} / \mathrm{L}$ & &
\end{tabular}

journals. Most literatures on this subject, therefore, are experiments conducted at the microcosm and pilot scales. This notwithstanding, a few studies had been documented. For example, Pantano, J., et al. [58] were successful in using a horizontal flow $\mathrm{CW}$ to remove $\mathrm{Cd}, \mathrm{Zn}$ and $\mathrm{Cu}$ from mining impacted groundwater while Gerth, A., et al. [59] used a hybrid free water surface and horizontal flow CW to treat seepage water from a uranium mine in Germany.

\subsubsection{Treatment Performance and Limitations}

The removal of toxic metals from mining wastewater using physico-chemical approaches such as adsorption, oxidation and reduction and chemical precipitation require large quantities of chemical reagents and produce a considerable amount of toxic sludge and secondary pollutants, thus raising questions about the sustainability of these technologies [27]. Conventional wastewater treatment systems such as the activated sludge treatment system are known to perform better in the removal of heavy metals than WSPs.

One limitation of WSPs in heavy metal removal is its inability to overcome shock loadings due to the low presence of microorganisms [24]. This limitation was overcomed by the introduction of attached growth medium which resulted in significant increase in heavy metal removal [25]. In the absence of such modifications, WSPs had to operate at very low organic loadings for metal removal. The use of $\mathrm{CW}$ in treating mining wastewater is also limited to the polishing stages of treatment as influent of high suspended solids can lead to clogging.

Ustun, G. E. [23] reported in a study involving nine metals ( $\mathrm{Al}, \mathrm{Cd}, \mathrm{Cr}, \mathrm{Cu}, \mathrm{Fe}, \mathrm{Mn}, \mathrm{Ni}, \mathrm{Pb}$ and $\mathrm{Zn}$ ) that while the WSP removed over $50 \%$ in $\mathrm{Al}$ and $\mathrm{Cr}$, for the other metals removals were less than $20 \%$ compared with the activated sludge system which a range of removals from $47 \%$ in $\mathrm{Ni}$ to $95 \%$ for $\mathrm{Cr}$. Polprasert, C. and Charnpratheep, K. [25] observed that when a medium is provided in WSPs for the adsorption of metals, the performance of the WSPs can increase significantly. Sekomo, C. B., et al. [60] using synthetic wastewater, however, reported a removal rate of $\mathrm{Cr}$ of $94 \%$ and $98 \%$ for a duckweed and algal pond systems respectively. The researchers noted that the rates of removal obtained occurred 
irrespective of the loading rate or the light regime. In that same study, using a light-darkness regime of $16 \mathrm{~h}$ light/8 h darkness, Sekomo, C. B., et al. [60] recorded a $\mathrm{Zn}$ removal rate of $70 \%$ at a lower loading rate, which dropped to a removal rate of $40 \%$ when the loading rate was increased. The removal efficiency rose back to $80 \%$ at the higher metal loading rate but under $24 \mathrm{~h}$ light regime. $\mathrm{Pb}, \mathrm{Cd}$ and $\mathrm{Cu}$ all showed relatively similar patterns with removal efficiencies of $36 \%$ and $33 \%$ for $\mathrm{Pb}, 33 \%$ and $21 \%$ for $\mathrm{Cd}$ and $27 \%$ and $29 \%$ for $\mathrm{Cu}$ in the duckweed and the algal ponds, respectively in that study. In biological wastewater treatment, metal removal efficiency depends on the metal species and concentration, the reactivity of the available biopolymers or biomass and the composition of other wastewater components [61]. Sekomo, C. B., et al. [60], however, observed that inspite of the physico-chemical differences among the duckweed and algal ponds, differences in metal removal efficiency between algal and duckweed ponds were rather small. As Table 2 shows, CW offers a viable alternative for the removal of metals from mining wastewater.

\subsubsection{Mechanisms of Metal Removal}

In waste stabilization ponds, the removals of metals occur through a process of adsorption unto suspended solids and biomass, with subsequent sedimentation of adsorbed metals. This takes place mainly in the anaerobic pond and to some extent the facultative ponds. The metal removal efficiency depends on the metal species and concentration, the reactivity of the available biopolymers or biomass and the composition of other wastewater components [61]. Thus the formation of metal complexes and dissolution values for each metal are different resulting in varying removal efficiency for each metal type [66]. As mentioned earlier, the low amount of medium for adsorption by metals in WSPs limits the extent of its removal in WSPs.

Mechanisms involved in heavy metal removal in CWs, include a combination of sedimentation, filtration, binding to substrata, precipitation as insoluble salts such as sulphides or oxyhydroxides and accumulation by plants, algae and/or bacteria [67].

It has been argued that substrates act as primary sink for heavy metal accumulation and that the bulk of the influent heavy metal is removed by accumulation in the ground biomass and not the above ground biomass of plants [27, 68].

Heavy metal uptake varies from one plant species to another in CWs. However, Yadav, A. K., et al. [27] noted that in all three plant species involving Canna indica, Typha angustifolia and Cyperus alternifolius in a VSSF (Vertical Subsurface Flow), the contribution of the below ground biomass (roots) was more than the above ground biomass (leaves and stem) in the removal of $\mathrm{Cu}, \mathrm{Cr}, \mathrm{Co}, \mathrm{Ni}$ and $\mathrm{Zn}$ from aqueous solution. They also noted that the removal of $\mathrm{Cr}, \mathrm{Ni}$, $\mathrm{Cu}, \mathrm{Zn}$ and $\mathrm{Co}$ was enhanced by $16.6 \%, 22.9 \%$, $20.4 \%, 21.5 \%$ and $21.8 \%$ respectively, when gravel bed depth of CWs was increased from $0.3 \mathrm{~m}$ to $1.5 \mathrm{~m}$, showing that enhanced gravel bed depth may improve the performance of CWs in metal removal.

In addition to taking up metal, the root network also filters fine particulate matter, for which sedimentation is slower than for larger particles. Through the biofilm that forms on the surface of the roots, significant biological activity develops and could intervene in the process of biodegradation of other pollutants, such as hydrocarbons [69].

It has been suggested that plants used for the uptake of heavy metals must be mowed yearly to harvest biomass and recover pollutants and these plants used for providing fuel [69].

\subsubsection{Economics of Heavy Metal Removal}

In determining the suitability of a technology for treating wastewater, key considerations are given to its robustness while meeting effluent standards, extent of chemical usage and the degree of environmental nuisance it poses, capacity for various re-use options as well as environmental benefits, greenhouse gas emissions and its energy and capital requirements [70, 71]. The high purification rates $[72,73]$, robustness 
Table 2 Performance of various types of CWs in the removal of metals from mining wastewater.

\begin{tabular}{|c|c|c|c|c|}
\hline Metal/CW type & $\begin{array}{l}\text { Influent concentration } \\
(\mathrm{mg} / \mathrm{L})\end{array}$ & Retention time & $\begin{array}{l}\text { Removal } \\
(\%)\end{array}$ & Literature reference \\
\hline $\mathrm{Al} / \mathrm{VSSF}$ & 0.51 & 79 days & 100.0 & {$[64]$} \\
\hline $\mathrm{As} / \mathrm{HSSF}$ & 2.3 & 11 days & 99.9 & {$[65]$} \\
\hline $\mathrm{Zn} / \mathrm{VSSF}$ & 3.19 & 36 days & 100.0 & {$[64]$} \\
\hline $\mathrm{Zn} / \mathrm{VSSF}$ & 20.0 & 72 hours & 99.3 & [27] \\
\hline $\mathrm{Zn} / \mathrm{HSSF}$ & 14.5 & 5-7 days & 97.3 & {$[63]$} \\
\hline $\mathrm{Pb} / \mathrm{VSSF}$ & 0.0105 & 36 days & 100.0 & {$[64]$} \\
\hline $\mathrm{Pb} / \mathrm{HSSF}$ & 11.5 & 5-7 days & 99.0 & {$[63]$} \\
\hline $\mathrm{Ni} / \mathrm{VSSF}$ & 20.0 & 72 hours & 76.4 & [27] \\
\hline $\mathrm{Cd} / \mathrm{VSSF}$ & 0.0066 & 36 days & 100.0 & {$[64]$} \\
\hline $\mathrm{Cd} / \mathrm{HSSF}$ & 0.05 & 5-7 days & 94.0 & {$[63]$} \\
\hline $\mathrm{Fe} / \mathrm{HSSF}$ & 97.3 & 11 days & 96.1 & {$[65]$} \\
\hline $\mathrm{Mn} / \mathrm{VSSF}$ & 0.206 & 79 days & 100.0 & [64] \\
\hline $\mathrm{Co} / \mathrm{VSSF}$ & 20.0 & 72 hours & 54.6 & {$[27]$} \\
\hline $\mathrm{Cu} / \mathrm{VSSF}$ & 20.0 & 72 hours & 68.3 & {$[27]$} \\
\hline $\mathrm{Cu} / \mathrm{VSSF}$ & 0.73 & 30 days & 100.0 & {$[64]$} \\
\hline $\mathrm{Cr} / \mathrm{VSSF}$ & 20.0 & 72 hours & 66.2 & {$[27]$} \\
\hline
\end{tabular}

Note: HSSF CW: Horizontal Subsurface Flow Constructed Wetland; VSSF CW: Vertical Subsurface Flow Constructed Wetland.

and operational stability [74, 75], low skilled manpower and capital requirement [76, 77], ecological benefits [71, 75-79] as well as direct economic benefits such as fish farming $[75,76]$ of WSPs and CWs are well documented in literature. For the treatment of mining wastewater, however, particular importance is attached to the energy requirement as well as the carbon footprint of the treatment technology.

\section{Energy Requirement}

Adequate water supply is important for mining operations and as water is one of key business risks for the industry [80], the use of sustainable technologies that treat and use water efficiently is a must. Using the LCA (Life Cycle Analysis) approach, Brix, H. [81] compared the energy requirements of three system types namely, CWs, wastewater aquaculture facilities and conventional wastewater treatment technologies. The results revealed that the CWs require very low energy compared to the others. Austin, D. and Nivala, J. [82] investigated the energy requirements of three wetland technologies: aerated subsurface flow, tidal flow and pulse-fed wetland treatment as engineered wetlands, and compared them to that of a mechanical activated-sludge treatment system. Their results showed that the electrical power requirements for the wetland systems were $0-56 \%$ of that of activated-sludge treatment systems. These findings agreed with a study by Zhou, J. B., et al. [83], which used a different approach involving emergy synthesis. Emergy is described as the available energy of one kind previously required to be used up directly and indirectly to make a product or service $[84,85]$. Shao, L., et al. [86] in adopting the input-output energy approach of system accounting estimated that the energy embodied in treating per $\mathrm{m}^{3}$ of wastewater and removing per $\mathrm{kg}$ BOD (Biochemical Oxygen Demand), COD (Chemical Oxygen Demand), SSs (Suspended Solids) and $\mathrm{NH}_{3}-\mathrm{N}$ by a $\mathrm{CW}$ is only $6.83 \%, \quad 17.48 \%, \quad 13.96 \%, \quad 22.47 \%$ and $9.48 \%$ respectively of that by a conventional system. Studies that compare the energy requirement of WSPs and CWs for treating mining wastewater is rare but Mara, D. D. [87] showed that on the basis of land area requirement, capital, operating and maintenance costs, WSPs are to be preferred to SSF (Surface Flow) CW. As CWs perform better in metal removal than WSPs, 
it can be argued that to obtain a performance equal or better than that of a CW, more energy, land area may be required. Thus a key research question would be how much more energy would be required.

\section{Greenhouse Gas Emissions}

One of the factors to consider in assessing the economic viability of a wastewater treatment technology is its carbon footprint. Mander, U., et al. [88] noted that the emission factor of methane in FWS (Free Water Surface) and HSSF CWs is very high and yet the absolute value of methane emission is relatively small in the order of 1-2 magnitudes lower than that found in conventional wastewater treatment plants. In their review, they further observed that carbon dioxide emission in FWS $\mathrm{CW}$ was significantly lower than that of SF (Subsurface Flow) CWs while methane emission in VSSF CWs was also lower than in HSSF CWs. However, in that same study, no real differences were observed among the various types of $\mathrm{CW}$ in the emission of nitrousoxide. The median values for FWS, VSSF and HSSF CWs were $0.09 \mathrm{mg} \cdot \mathrm{m}^{-2} \cdot \mathrm{h}^{-1}, \quad 0.12 \mathrm{mg} \cdot \mathrm{m}^{-2} \cdot \mathrm{h}^{-1}$ and 0.13 $\mathrm{mg} \cdot \mathrm{m}^{-2} \cdot \mathrm{h}^{-1}$, respectively.

Sims, A., et al [89] showed that a duckweed covered WSP emitted 504-1,900 mg methane and 1,700-3,300 mg carbon dioxide $\mathrm{m}^{-2} \cdot \mathrm{d}^{-1}$. FWS CW resembles WSPs in its biochemical and physical processes [90] and is therefore likely that emissions in FWS and WSPs may be similar. Studies comparing the emission rates of GHG (Green House Gas) in these treatment technologies using the same source of wastewater are rare.

GHG emissions in WSPs and CWs can be affected by various operating conditions. Methane flux properties, activities of methanogens and methanotrophs and the relationship between methane flux rate and some environmental parameters are known to be different in different plant species of $\mathrm{CW}$ systems. The difference in emission intensity varied with the different vegetation cover and seasonal fluctuations [91]. In that same study by Wang, Y., et al. [91], they noted that, for the same aquatic plant species, the difference in emission intensity varied with influent pollutant concentrations, the methane emission data showing large spatial and temporal variation ranging from 0 to $16.76 \mathrm{~g} \mathrm{CH}_{4} \mathrm{~m}^{-2} \cdot \mathrm{day}^{-1}$ with higher emissions occurring when influent loadings are high. Mander, U., et al. [88] also noted that overloading a HSSF CW led to elevated methane emissions. Further studies on GHG emissions for treating mining wastewater is necessary, taking into consideration variations created by hydrological regimes, microbial communities and plant species.

\section{Concluding Remarks}

Pollution of the environment with heavy metals is widespread and often involves large volumes of wastewater. Remediation strategies for mining wastewater must be designed to support high throughput while keeping costs to a minimum. Biosorption is an alternative to traditional physicochemical means for removing toxic metals from wastewater. Biosorption can quickly and effectively remove dissolved metals out of dilute complex solution with high efficiency. These characteristics make biosorption an ideal candidate for the treatment of high volumes of low concentration complex mining wastewater. However, preparing biosorption for application as a process requires a strong chemical engineering background, and an understanding of the sorption operation is a must. Research showed that the down-flow fixed-bed treatment configuration is an ideal system for the simultaneous removal of heavy metals from low concentration mining effluent. For industrial application of biosorption, regeneration of the biosorbents is important in keeping the process costs down and opening the possibility of recovering the metal ion extracted from the liquid phase. Where the treated effluent characteristic did not meet the discharge requirement, $\mathrm{CW}$ and WSP treatment 
system can be used to polish the effluent from the biosorption system.

Studies conducted on the use of CWs and WSPs in particular for treating mining wastewater are few. Available evidence suggests that WSPs perform poorly in metal removal due to the low density of suspended solids in the treatment system as removal is mainly through adorption unto suspended solids. The introduction of attached growth medium into the pond system therefore can result in significant increase in heavy metal removal. This growth medium can also increase WSPs ability to overcome shock loadings. CWs, however, perform better in heavy metal removal than WSPs. The removal efficiency of CWs however is known to be affected by the metal species and concentration, the reactivity of the available biopolymers or biomass, and the composition of other wastewater components as well as its exposure to sunlight. The formation of metal complexes and dissolution values for each metal species are different resulting in varying removal efficiency for each metal type. In terms of cost of treatment, a key consideration is the energy requirement and its greenhouse gas emissions.

\section{References}

[1] Vilar, V. J., Botelho, C. M., and Boaventura, R. A. 2008. "Lead and Copper Biosorption by Marine Red Algae Gelidium and Algal Composite Material in a CSTR (“Carberry" Type)." Chemical Engineering Journal 138 (1): 249-57.

[2] Izquierdo, M., Gabaldon, C., Marzal, P., and Alvarez-Hornos, F. J. 2010. "Modeling of Copper Fixed-bed Biosorption from Wastewater by Posidonia Oceanica." Bioresource Technology 101 (2): 510-7.

[3] Oguz, E., and Ersoy, M. 2010. "Removal of $\mathrm{Cu}^{2+}$ from Aqueous Solution by Adsorption in a Fixed Bed Column and Neural Network Modelling." Chemical Engineering Journal 164 (1): 56-62.

[4] Kumar, R., Bhatia, D., Singh, R., Rani, S., and Bishnoi, N. R. 2011. "Sorption of Heavy Metals from Electroplating Effluent Using Immobilized Biomass Trichoderma Viride in a Continuous Packed-bed Column." International Biodeterioration \& Biodegradation 65 (8): 1133-9.

[5] Martin-Lara, M. A., Blazquez, G., Ronda, A., Rodriguez,
I. L., and Calero, M. 2012. "Multiple Biosorption-Desorption Cycles in a Fixed-bed Column for Pb(II) Removal by Acid-treated Olive Stone.” Journal of Industrial and Engineering Chemistry 18 (3): 1006-12.

[6] Kaczala, F., Marques, M., and Hogland, W. 2009. "Lead and Vanadium Removal from a Real Industrial Wastewater by Gravitational Settling/Sedimentation and Sorption onto Pinus Sylvestris Sawdust." Bioresource Technology 100 (1): 235-43.

[7] Azimi, A., Azari, A., Rezakazemi, M., and Ansarpour, M. 2016. "Removal of Heavy Metals from Industrial Wastewaters: A Review." ChemBioEng Reviews 4: 37-59.

[8] Izquierdo, M., Marzal, P., Gabaldon, C., Silvetti, M., and Castaldi, P. 2012. "Study of the Interaction Mechanism in the Biosorption of Copper(II) Ions onto Posidonia Oceanica and Peat." CLEAN—Soil, Air, Water 40 (4): 428-37.

[9] Mondal, M. K. 2009. "Removal of $\mathrm{Pb}$ (II) Ions from Aqueous Solution Using Activated Tea Waste: Adsorption on a Fixed-bed Column." Journal of Environmental Management 90 (11): 3266-71.

[10] Benavente, M., Moreno, L., and Martinez, J. 2011. "Sorption of Heavy Metals from Gold Mining Wastewater Using Chitosan." Journal of the Taiwan Institute of Chemical Engineers 42 (6): 976-88.

[11] Mohan, D., and Chander, S. 2006. "Removal and Recovery of Metal Ions from Acid Mine Drainage Using Lignite-A Low Cost Sorbent." Journal of Hazardous Materials 137 (3): 1545-53.

[12] Sousa, F. W., Sousa, M. J., Oliveira, I. R., Oliveira, A. G., Cavalcante, R. M., Fechine, P. B., et al. 2009. "Evaluation of a Low-Cost Adsorbent for Removal of Toxic Metal Ions from Wastewater of an Electroplating Factory." Journal of Environmental Management 90 (11): 3340-4.

[13] Acheampong, M. A., Pereira, J. P., Meulepas, R. J., and Lens, P. N. 2011. "Biosorption of $\mathrm{Cu}(\mathrm{II})$ onto Agricultural Materials from Tropical Regions." Journal of Chemical Technology \& Biotechnology 86 (9): 1184-94.

[14] Fu, F., and Wang, Q. 2011. "Removal of Heavy Metal Ions from Wastewaters: A Review." Journal of Environmental Management 92 (3): 407-18.

[15] Park, D., Yun, Y. S., and Park, J. M. 2010. "The Past, Present, and Future Trends of Biosorption." Biotechnology and Bioprocess Engineering 15 (1): 86-102.

[16] Sousa, F. W., Oliveira, A. G., Ribeiro, J. P., Rosa, M. F., Keukeleire, D., and Nascimento, R. F. 2010. "Green Coconut Shells Applied as Adsorbent for Removal of Toxic Metal Ions Using Fixed-bed Column Technology." 
Journal of Environmental Management 91 (8): 1634-40.

[17] Kleinubing, S. J., Guibal, E., Da Silva, E. A., and Da Silva, M. G. C. 2012. "Copper and Nickel Competitive Biosorption Simulation from Single and Binary Systems by Sargassum Filipendula." Chemical Engineering Journal 184: 16-22.

[18] Singh, P., Bajpai, J., Bajpai, A. K., and Shrivastava, R. B. 2011. "Fixed-bed Studies on Removal of Arsenic from Simulated Aqueous Solutions Using Chitosan Nanoparticles." Bioremediation Journal 15 (3): 148-56.

[19] Kirbiyik, C., Putun, A. E., and Putun E. 2016. "Comparative Studies on Adsorptive Removal of Heavy Metal Ions by Biosorbent, Bio-char and Activated Carbon Obtained from Low Cost Agro-residue." Water Science and Technology 73 (2): 423-36.

[20] Carmona, M. E. R., Da Silva, M. A. P., Leite, S. G. F., Echeverri, O. H. V., and Ocampo-Lopez, C. 2012. "Packed Bed Redistribution System for Cr(III) and Cr(VI) Biosorption by Saccharomyces Cerevisiae." Journal of the Taiwan Institute of Chemical Engineers 43 (3): 428-32.

[21] Jain, C. K., Malik, D. S., and Yadav, A. K. 2016. "Applicability of Plant Based Biosorbents in the Removal of Heavy Metals: A Review." Environmental Processes 3 (2): 495-523.

[22] Singh, A., Kumar, D., and Gaur, J. P. 2012. "Continuous Metal Removal from Solution and Industrial Effluents Using Spirogyra Biomass-packed Column Reactor." Water Research 46 (3): 779-88.

[23] Ustun, G. E. 2009. "Occurrence and Removal of Metals in Urban Wastewater Treatment Plants." Journal of Hazardous Materials 172 (2): 833-8.

[24] Kaplan, D., Abeliovich, A., and Ben-Yaakov, S. 1987. "The Fate of Heavy Metals in Waste Stabilization Ponds." Water Research 21 (10): 1189-94.

[25] Polprasert, C., and Charnpratheep, K. 1989. "Heavy Metal Removal in Attached-growth Waste Stabilization Ponds." Water Research 23 (5): 625-31.

[26] Vymazal, J. 2009. "The Use Constructed Wetlands with Horizontal Sub-surface Flow for Various Types of Wastewater." Ecological Engineering 35 (1): 1-17.

[27] Yadav, A. K., Abbassi, R., Kumar, N., Satya, S., Sreekrishnan, T. R., and Mishra, B. K. 2012. "The Removal of Heavy Metals in Wetland Microcosms: Effects of Bed Depth, Plant Species, and Metal Mobility." Chemical Engineering Journal 211: 501-7.

[28] Wang, J., and Chen, C. 2009. "Biosorbents for Heavy Metals Removal and Their Future." Biotechnology Advances 27 (2): 195-226.

[29] Arief, V. O., Trilestari, K., Sunarso, J., Indraswati, N., and Ismadji, S. 2008. "Recent Progress on Biosorption of Heavy Metals from Liquids Using Low Cost Biosorbents:
Characterization, Biosorption Parameters and Mechanism Studies." CLEAN—Soil, Air, Water 36 (12): 937-62.

[30] Davis, T. A., Volesky, B., and Mucci, A. 2003. "A Review of the Biochemistry of Heavy Metal Biosorption by Brown Algae." Water Research 37 (18): 4311-30.

[31] Han, R., Zhang, J., Zou, W., Xiao, H., Shi, J., and Liu, H. 2006. "Biosorption of Copper(II) and Lead(II) from Aqueous Solution by Chaff in a Fixed-bed Column." Journal of Hazardous Materials 133 (1): 262-8.

[32] Vijayaraghavan, K., and Yun, Y. S. 2008. "Bacterial Biosorbents and Biosorption." Biotechnology Advances 26 (3): 266-91.

[33] Niu, H., and Volesky, B. 2003. "Characteristics of Anionic Metal Species Biosorption with Waste Crab Shells." Hydrometallurgy 71 (1): 209-15.

[34] Deng, S., and Ting, Y. P. 2005. "Characterization of PEI-modified Biomass and Biosorption of $\mathrm{Cu}(\mathrm{II}), \mathrm{Pb}(\mathrm{II})$ and Ni(II)." Water Research 39 (10): 2167-77.

[35] Sud, D., Mahajan, G., and Kaur, M. P. 2008. "Agricultural Waste Material as Potential Adsorbent for Sequestering Heavy Metal Ions from Aqueous Solutions-A Review.” Bioresource Technology 99 (14): 6017-27.

[36] Acheampong, M. A., and Lens, P. N. 2014. "Treatment of Gold Mining Effluent in Pilot Fixed Bed Sorption System." Hydrometallurgy 141: 1-7.

[37] Saad, D. M., Cukrowska, E. M., and Tutu, H. 2011. "Development and Application of Cross-linked Polyethylenimine for Trace Metal and Metalloid Removal from Mining and Industrial Wastewaters." Toxicological \& Environmental Chemistry 93 (5): 914-24.

[38] Botz, M. M., and Mudder, T. I. 2000. "Modeling of Natural Cyanide Attenuation in Tailings Impoundments." Minerals and Metallurgical Processing 17 (4): 228-33.

[39] Mudder, T. I., Botz, M., and Smith, A. 2001. "Chemistry and Treatment of Cyanidation Wastes (Second Edition)." Mining Journal Books Ltd, London, UK.

[40] Kunz, R. G., Casey, G., and Huff, J. 1979. "Refinery Cyanides: A Regulatory Dilemma." Hydrocarbon Processing 57 (10): 98-106.

[41] Ahmed, M. J. K., and Ahmaruzzaman, M. 2016. “A Review on Potential Usage of Industrial Waste Materials for Binding Heavy Metal Ions from Aqueous Solutions." Journal of Water Process Engineering 10: 39-47.

[42] Gadd, G. M. 2009. "Biosorption: Critical Review of Scientific Rationale, Environmental Importance and Significance for Pollution Treatment." Journal of Chemical Technology \& Biotechnology 84 (1): 13-28.

[43] Guo, X., Zhang, S., and Shan, X. Q. 2008. "Adsorption of Metal Ions on Lignin." Journal of Hazardous Materials 151(1): 134-42. 
[44] Tofighy, M. A., and Mohammadi, T. 2011. "Adsorption of Divalent Heavy Metal Ions from Water Using Carbon Nanotube Sheets." Journal of Hazardous Materials 185 (1): 140-7.

[45] Acheampong, M. A., Meulepas, R. J., and Lens, P. N. 2010. "Removal of Heavy Metals and Cyanide from Gold Mine Wastewater." Journal of Chemical Technology \& Biotechnology 85 (5): 590-613.

[46] Donmez, G., and Aksu, Z. 2002. "Removal of Chromium(VI) from Saline Wastewaters by Dunaliella Species." Process Biochemistry 38 (5): 751-62.

[47] Deng, L., Su, Y., Su, H., Wang, X., and Zhu, X. 2007. "Sorption and Desorption of Lead(II) from Wastewater by Green Algae Cladophora Fascicularis." Journal of Hazardous Materials 143 (1): 220-5.

[48] Gadd, G. M., White, C., and De Rome, L. 1988. "Heavy Metals and Radionuclide Uptake by Fungi and Yeasts." In Biohyhrometallurgy Science and Technology Letters, edited by Norris, P, R., and Kelly, D. P. Kew, Surry, UK, 421-35.

[49] Mohanty, K., Jha, M., Meikap, B. C., and Biswas, M. N. 2006. "Biosorption of $\mathrm{Cr}(\mathrm{VI})$ from Aqueous Solutions by Eichhornia Crassipes." Chemical Engineering Journal 117 (1): 71-7.

[50] Amuda, O. S., Giwa, A., and Bello, I. A. 2007. "Removal of Heavy Metal from Industrial Wastewater Using Modified Activated Coconut Shell Carbon." Biochemical Engineering Journal 36 (2): 174-81.

[51] Dundar, M., Nuhoglu, C., and Nuhoglu, Y. 2008. "Biosorption of $\mathrm{Cu}$ (II) Ions onto the Litter of Natural Trembling Poplar Forest." Journal of Hazardous Materials 151 (1): 86-95.

[52] Gupta, V. K., and Rastogi, A. 2008. "Biosorption of Lead from Aqueous Solutions by Green Algae Spirogyra Species: Kinetics and Equilibrium Studies." Journal of Hazardous Materials 152 (1): 407-14.

[53] Volesky, B. 2001. "Detoxification of Metal-bearing Effluents: Biosorption for the Next Century." Hydrometallurgy 59 (2): 203-16.

[54] Liu, H., Dong, Y., Wang, H., and Liu, Y. 2010. "Adsorption Behavior of Ammonium by a Bioadsorbent-Boston Ivy Leaf Powder." Journal of Environmental Sciences 22 (10): 1513-8.

[55] Liu, M., Deng, Y., Zhan, H., and Zhang, X. 2002. "Adsorption and Desorption of Copper(II) from Solutions on New Spherical Cellulose Adsorbent." Journal of Applied Polymer Science 84 (3): 478-85.

[56] Marin, J., and Ayele, J. 2003. "Removal of Some Heavy Metal Cations from Aqueous Solutions by Spruce Sawdust. II. Adsorption-Desorption through Column Experiments." Environmental Technology 24 (4): 491-502.
[57] Acheampong, M. A., Ansa, E. D. O., and Adiyiah, J. 2013. "Physico-Chemical Characteristics of a Gold Mining Tailings Dam Wastewater." Journal of Environmental Science and Engineering A 2 (8A): 469-75.

[58] Pantano, J., Bullock, R., McCarthy, D., Sharp, T., and Stilwell, C. 1999. "Using Wetlands to Remove Metals from Mining Impacted Groundwater." In Wetlands \& Remediation: An International Conference, 383-90, Battelle Press, Columbus, $\mathrm{OH}$.

[59] Gerth, A., Hebner, A., Kiessig, G., Kuchler, A., and Zellmer, A. 2005. "Passive Treatment of Minewater at the Schlema-Alberoda Site." In Book of Abstracts of the International Symposium on Wetland Pollutant Dynamics and Control, 53-4, Ghent University, Belgium.

[60] Sekomo, C. B., Rousseau, D. P., Saleh, S. A., and Lens. P. N. 2012. "Heavy Metal Removal in Duckweed and Algae Ponds as a Polishing Step for Textile Wastewater Treatment." Ecological Engineering 44: 102-10.

[61] Aklil, A., Mouflih, M., and Sebti, S. 2004. "Removal of Heavy Metal Ions from Water by Using Calcined Phosphate as a New Adsorbent." Journal of Hazardous Materials 112 (3): 183-90.

[62] Palmer, K., Ronkanen, A. K., and Klove, B. 2015. "Efficient Removal of Arsenic, Antimony and Nickel from Mine Wastewaters in Northern Treatment Peatlands and Potential Risks in Their Long-term Use.” Ecological Engineering 75: 350-64

[63] Yang, B., Lan, C. Y., Yang, C. S., Liao, W. B., Chang, H., and Shu, W. S. 2006. "Long-term Efficiency and Stability of Wetlands for Treating Wastewater of a Lead/Zinc Mine and the Concurrent Ecosystem Development." Environmental Pollution 143 (3): 499-512.

[64] Cheng, S., Grosse, W., Karrenbrock, F., and Thoennessen, M. 2002. "Efficiency of Constructed Wetlands in Decontamination of Water Polluted by Heavy Metals." Ecological Engineering 18 (3): 317-25.

[65] Allende, K. L., McCarthy, D. T., and Fletcher, T. D. 2014. "The Influence of Media Type on Removal of Arsenic, Iron and Boron from Acidic Wastewater in Horizontal Flow Wetland Microcosms Planted with Phragmites Australis." Chemical Engineering Journal 246: 217-28.

[66] Lester, J. N. 1983. "Significance and Behaviour of Heavy Metals in Wastewater Treatment Processes I. Sewage Treatment and Effluent Discharge." Science of the Total Environment 30: 1-44.

[67] Kadlec, R. H., and Knight, R. L. 1996. Treatment Wetlands. CRC Press, Lewis Publishers, Boca Raton, Florida, USA.

[68] Weis, J. S., and Weis, P. 2004. "Metal Uptake, Transport and Release by Wetland Plants: Implications for Phytoremediation and Restoration." Environment 
International 30 (5): 685-700.

[69] Ladislas, S., Gerente, C., Chazarenc, F., Brisson, J., and Andres Y. 2014. "Floating Treatment Wetlands for Heavy Metal Removal in Highway Stormwater Ponds." Ecological Engineering 80: 85-91.

[70] Brix, H. 1998. "How 'Green' Are Constructed Wetland Treatment Systems?" Presented at the 6th International Conference on Wetland Systems for Water Pollution Control, Brazil.

[71] Shutes, R. B. E. 2001. "Artificial Wetlands and Water Quality Improvement.” Environment International 26 (5): 441-7.

[72] Mara, D. D., Cairncross, S., and World Health Organization. 1989. "Guidelines for the Safe Use of Wastewater and Excreta in Agriculture and Aquaculture: Measures for Public Health Protection." Geneva: World Health Organization.

[73] Steinmann, C. R., Weinhart, S., and Melzer, A. 2003. “A Combined System of Lagoon and Constructed Wetland for an Effective Wastewater Treatment." Water Research 37 (9): 2035-42.

[74] Tanner, C. C., Craggs, R. J., Sukias, J. P. S., and Park, J. B. K. 2005. "Comparison of Maturation Ponds and Constructed Wetlands as Final Stage of an Advanced Pond System." Water Science and Technology 51 (12): 307-14.

[75] Gray, N. F. 2010. Water Technology: An Introduction for Environmental Scientists and Engineers (No. Ed. 3). IWA Publishing.

[76] Denny, P. 1997. "Implementation of Constructed Wetlands in Developing Countries." Water Science and Technology 35 (5): 27-34.

[77] Mara, D. D. 2013. Domestic Wastewater Treatment in Developing Countries. Routledge.

[78] Brissaud, F. 2008. "Low Technology Treatment Systems for Water Reuse in Small Municipalities." Sust. Water Manage 1: 3-8.

[79] Mungray, A. K., and Patel, K. 2011. "Coliforms Removal in Two UASB and ASP Based Systems." Int. Biodeterioration \& Biodegradation 65 (1): 23-8.

[80] Nguyen, M. T., Ziemski, M., and Vink, S. 2014. "Application of an Exergy Approach to Understand Energy Demand of Mine Water Management Options." Journal of Cleaner Production 84: 639-48.
[81] Brix, H. 1999. “How 'Green' Are Aquaculture, Constructed Wetlands and Conventional Wastewater Treatment Systems?" Water Science and Technology 40 (3): 45-50.

[82] Austin, D., and Nivala, J. 2009. "Energy Requirements for Nitrification and Biological Nitrogen Removal in Engineered Wetlands." Ecological Engineering 35 (2): 184-92.

[83] Zhou, J. B., Jiang, M. M., Chen, B., and Chen, G. Q. 2009. "Emergy Evaluations for Constructed Wetland and Conventional Wastewater Treatments." Communications in Nonlinear Science and Numerical Simulation 14 (4): 1781-9.

[84] Odum, H. T. 1988. "Self-organization, Transformity, and Information." Science (Washington) 242 (4882): 1132-6.

[85] Scienceman, D. M. 1987. "Energy and Emergy." Environmental Economics, 257-76.

[86] Shao, L., Wu, Z., Zeng, L., Chen, Z. M., Zhou, Y., and Chen, G. Q. 2013. "Embodied Energy Assessment for Ecological Wastewater Treatment by a Constructed Wetland." Ecological Modelling 252: 63-71.

[87] Mara, D. D. 2006. "Constructed Wetlands and Waste Stabilization Ponds for Small Rural Communities in the United Kingdom: A Comparison of Land Area Requirements, Performance and Costs." Environmental Technology 27 (7): 753-7.

[88] Mander, U., Dotro, G., Ebie, Y., Towprayoon, S., Chiemchaisri, C., Nogueira, S. F., et al. 2014. "Greenhouse Gas Emission in Constructed Wetlands for Wastewater Treatment: A Review." Ecological Engineering 66: 19-35.

[89] Sims, A., Gajaraj, S., and Hu, Z. 2013. "Nutrient Removal and Greenhouse Gas Emissions in Duckweed Treatment Ponds." Water Research 47 (3): 1390-8.

[90] USEPA (United States Environmental Protection Agency). 2002. "Constructed Wetlands for Wastewater Treatment and Wild Life Habitat." Office of Wetlands, Oceans and Watersheds, USEPA, Cincinnati, Ohio, USA.

[91] Wang, Y., Inamori, R., Kong, H., Xu, K., Inamori, Y., Kondo, T., et al. 2008. "Influence of Plant Species and Wastewater Strength on Constructed Wetland Methane Emissions and Associated Microbial Populations." Ecological Engineering 32 (1): 22-9. 